\title{
Growth responses, excreta quality, nutrient digestibility, bone development and meat yield traits of broiler chickens fed vegetable or animal protein diets
}

\author{
M.A. Hossain, A.F. Islam \& P.A. Iji \\ Department of Animal Science, School of Environmental and Rural Science, University of New England, Armidale, \\ NSW 2351, Australia
}

(Received 19 April 2012; Accepted 5 March 2013; First published online 31 July 2013)

\author{
Copyright resides with the authors in terms of the Creative Commons Attribution 2.5 South African Licence. \\ See: http://creativecommons.org/licenses/by/2.5/za \\ Condition of use: The user may copy, distribute, transmit and adapt the work, but must recognise the authors and the South African Journal of \\ Animal Science.
}

\begin{abstract}
This study was carried out to compare the performance of broilers fed diets containing only vegetable protein (VP) with birds that received an animal protein (AP) in their diets. Cobb 500 day-old male broiler chicks $(\mathrm{n}=256)$ were randomly divided into four experimental groups. The two AP diets contained fish meal and soybean (SBF) and fish meal with canola (CMF); while the two VP diets contained predominantly soybean (SBM) or canola (CAN) meals. All diets were isoenergetic and isonitrogenous, and were pelleted, but amino acid levels were formulated on a total and not digestible basis. Feed intake up to 21 days was highest on the AP diets, and the lowest in the SBM treatment. Birds in the AP diet groups were significantly heavier at 21 days and 35 days than those on the VP diets. Up to 35 days, birds on AP diets had superior feed conversion ratio, while the CAN treatment was the poorest. Excreta moisture level was significantly higher in birds fed the VP diets than those on AP diets. Excreta $\mathrm{pH}$ and ammonia concentration were similar between treatments. Protein digestibility was higher in the AP than in the VP diets. Birds raised on VP diets had a significantly lower abdominal fat content than birds on the AP diets. Other meat characteristics measured in this experiment did not differ significantly. Bone development, in terms of breaking strength and latency-to-sit time, was significantly better on the AP diets than that of birds on the VP diets. The birds on the CMF diet had the longest tibia bone, while birds on SBM diet, the shortest. Total tibia ash content on the CMF diet was significantly increased, along with its iron and copper concentration, which were also significantly higher in birds on the same diet than the others. The responses of birds generally indicated that the AP diets were superior to the VP diets.
\end{abstract}

Keywords: Growth, digestibility, fish meal, bone growth, meat quality, soybean meal, canola meal

\#Corresponding author: piji@une.edu.au

\section{Introduction}

Animal by-products and processed animal proteins are commonly used in poultry diets as conventional feed resources to meet the essential nutrient requirements of broiler chickens. In some countries these feedstuffs are excluded from poultry diets in order to prevent cross-contamination of diets for ruminant animals in situations where feed mills are shared. The exclusion of these feed ingredients from formulations not only reduces the nutritive value of the diets, but also limits the ability of the formulations to meet the essential nutrient requirements for poultry (Hossain et al., 2011a).

The protein requirements of poultry are most commonly met by vegetable and animal proteins. Animal by-products (meat meal, meat and bone meal, fish meal) are the most commonly used animal proteins in poultry diets and are considered excellent protein sources for chickens (Parsons et al., 1997; Giang et al., 2001). Despite being satisfactory sources of quality proteins, there are many constraints to the extensive use of animal by-products in diet formulation for poultry, the key one being the risk of zoonotic diseases. Furthermore, a critical cost appraisal of poultry feed formulations shows that protein of animal origin is more expensive than vegetable protein (VP) sources (Oluyemi \& Roberts, 2000). 
In view of this, there is a need to investigate the possibility of developing alternative VP diets for poultry. Meat chicken productions based entirely on vegetable ingredients may be an emerging trend for producers, and be in great demand from consumers as well. Broilers grown exclusively on VP diets are preferred in the European Union and Middle East (Mendes, 2003). This tendency is intensifying the pressure on feed formulators and nutritionists to supply organic, safe and hygienic poultry products to consumers, by providing quality diets to poultry without using animal by-products or growth promoters. Incorporation of vegetable ingredients, notably soybean, canola, sunflower and mustard, in diets, instead of using animal meals as a protein source, can lead to satisfactory broiler performance as long as the diets are properly balanced with necessary nutrients such as digestible amino acids. These ingredients are a good source of nutrients, are comparatively inexpensive, easily available, and easy to process, and pose less risk of disease contamination.

However, vegetable sources contain numerous anti-nutritive factors (ANF), are lower in protein quality, have a lower digestibility and a lower biological value than animal protein sources (Liener, 1980; Tacon, 1992). Diets formulated with vegetable proteins may possibly be nutritionally inferior to diets with animal protein (AP), and broilers fed solely on vegetable proteins will respond negatively. This study was undertaken to ascertain the growth responses, excreta quality, nutrient digestibility, leg bone development and meat yield characteristics of broiler chickens fed diets containing either vegetable or animal protein sources.

\section{Materials and Methods}

Two hundred and fifty-six day-old male Cobb 500 broiler chicks, weighing $46.0 \pm 0.88 \mathrm{~g}$, were randomly distributed into four dietary treatment groups. Each treatment had eight replicates consisting of eight birds per replicate. The birds were reared from day 1 to 35 days of age. The chicks were reared in brooder cages $(42 \times 75 \times 25 \mathrm{~cm})$ set up in an environmentally controlled room for the first three weeks and then transferred to larger AME cages. For the first two days, the birds were provided with a temperature of $33{ }^{\circ} \mathrm{C}$. The temperature was then gradually reduced by $1{ }^{\circ} \mathrm{C}$ or $2{ }^{\circ} \mathrm{C}$ every one or two days until the chicks were 19 days old, at which point the temperature was maintained at $24{ }^{\circ} \mathrm{C}$ for the rest of the trial. Eighteen hours of lighting per day was provided throughout the trial period.

The experimental diets were formulated from maize, wheat and vegetable oil as the main energy sources, and protein sources in different combinations (Tables 1 and 2), and the diets were pelleted. The diets were formulated to meet or exceed NRC (1994) recommendations. The VP diets contained predominantly soybean (SBM) or canola (CAN) meals; diet SBM contained soybean and canola at a ratio of $3: 1$, and the CAN diet at a ratio of $1: 3$. As protein sources the two animal protein diets contained fish meal, and different ratios of soybean and canola meal. Diet SBF contained soybean and canola at a ratio of $2: 1$, and diet CMF at a $1: 2$ ratio. Fish meal was included at $7.74 \%$ and $8.39 \%$ in the SBF and CMF starter diets, respectively, and at $7.18 \%$ and $7.0 \%$ in finisher diets, respectively. All experimental diets were isoenergetic and isonitrogenous and supplemented with exogenous enzymes (Avizyme $0.5 \mathrm{~g} / \mathrm{kg}$ and Phyzyme, $0.1 \mathrm{~g} / \mathrm{kg}$ diet) as well as zinc bacitracin $(0.5 \mathrm{~g} / \mathrm{kg})$. Titanium dioxide $\left(\mathrm{TiO}_{2}\right)$ was incorporated into each diet at a rate of 5 $\mathrm{g} / \mathrm{kg}$ as an indigestible marker to enable assessment of nutrient digestibility. The birds were fed starter diets for the first three weeks and finisher diets for the last two weeks of the experiment.

Mortality was recorded as it occurred, while body weight and feed intake were recorded weekly for the calculation of body weight gain and feed conversion ratio (FCR), after correcting for mortality. On day 14, excreta samples were collected from each cage to determine the ammonia concentration, $\mathrm{pH}$ and moisture content as measures of excreta quality. Four birds from each cage were randomly selected, weighed and killed by cervical dislocation to collect digesta samples from the ileum for the assessment of nutrient (gross energy, protein and starch) digestibility on day 21. On day 28, leg bone development was assessed through latency-to-sit (LTS) and gait scoring tests. The LTS test was performed according to the method of Berg \& Sanotra (2003), with some modifications. A plastic tub containing warm water $\left(32^{\circ} \mathrm{C}\right)$ to a depth of $3 \mathrm{~cm}$ was used. Two birds from each replicate were randomly selected from the cage and put into the water tub. The birds were observed and left standing in the tubs of water for up to 15 minutes. The time that elapsed before the birds first attempted to sit down in the water was recorded in seconds with the aid of a stopwatch. If any bird was still standing after 15 minutes, the test was terminated. 
Table 1 Composition of starter diets

\begin{tabular}{|c|c|c|c|c|}
\hline & \multicolumn{4}{|c|}{ Experimental treatments } \\
\hline & SBM & CAN & SBF & CMF \\
\hline \multicolumn{5}{|c|}{ Ingredient composition (g/kg) } \\
\hline Maize & 405.9 & 377.5 & 414.0 & 617.0 \\
\hline Wheat & 210.0 & 187.5 & 203.8 & 0.0 \\
\hline Vegetable oil & 0.0 & 20.0 & 0.0 & 0.0 \\
\hline Soybean meal & 246.9 & 93.8 & 154.9 & 84.0 \\
\hline Canola meal & 82.3 & 281.3 & 77.5 & 167.9 \\
\hline Fish meal & 0.0 & 0.0 & 77.5 & 84.0 \\
\hline Limestone & 20.1 & 13.5 & 25.7 & 12 \\
\hline Dicalcium phosphate & 18.4 & 10.9 & 30.0 & 14 \\
\hline DL-Methionine & 2.0 & 1.4 & 2.2 & 1.5 \\
\hline Lysine & 1.7 & 1.2 & 2.1 & 1.9 \\
\hline Sodium chloride & 3.5 & 4.0 & 3.2 & 3.7 \\
\hline Vit.-min. premix ${ }^{1}$ & 2.5 & 2.25 & 2.5 & 2.5 \\
\hline Choline chloride & 0.6 & 0.6 & 0.6 & 0.6 \\
\hline Avizyme 1502 & 0.5 & 0.5 & 0.5 & 0.5 \\
\hline Phyzyme XP & 0.1 & 0.1 & 0.1 & 0.1 \\
\hline Zinc bacitracin & 0.5 & 0.5 & 0.5 & 0.5 \\
\hline Marker $\left(\mathrm{TiO}_{2}\right)$ & 5.0 & 5.0 & 5.0 & 5.0 \\
\hline \multicolumn{5}{|l|}{ Nutrient composition (g/kg) } \\
\hline ME (MJ/kg) & 12.38 & 12.38 & 12.39 & 12.38 \\
\hline Crude protein & 210.0 & 211.1 & 211.1 & 211.5 \\
\hline Crude fibre & 30.5 & 37.0 & 28.0 & 34.0 \\
\hline Ether extract & 24.0 & 28.4 & 29.3 & 32.2 \\
\hline Calcium & 11.5 & 11.0 & 12.8 & 12.4 \\
\hline Available P & 5.2 & 5.3 & 6.4 & 6.2 \\
\hline Sodium & 2.0 & 2.0 & 2.2 & 2.1 \\
\hline Chlorine & 2.5 & 2.7 & 2.7 & 2.5 \\
\hline Lysine & 13.0 & 12.1 & 13.7 & 13.4 \\
\hline Methionine + cystine & 8.3 & 8.3 & 8.4 & 8.4 \\
\hline Threonine & 8.2 & 8.4 & 8.4 & 8.5 \\
\hline Arginine & 14.2 & 13.0 & 14.0 & 13.0 \\
\hline
\end{tabular}

\footnotetext{
SBM: vegetable protein diets containing predominantly soybean;

CAN: vegetable protein diets containing predominantly canola;

SBF: animal protein diet containing fish meal and soybean;

SMF: animal protein diet containing fish meal with canola.

${ }^{1}$ Provided per kg of diet (mg): $3.6 \mathrm{mg}$ vitamin A (as all-trans retinol); $0.09 \mathrm{mg}$ cholecalciferol; $44.7 \mathrm{mg}$ vitamin $\mathrm{E}$ (as $\mathrm{d}$ - $\alpha$-tocopherol); $2 \mathrm{mg}$ vitamin $\mathrm{K}_{3} ; 2 \mathrm{mg}$ thiamine; $6 \mathrm{mg}$ riboflavin; $5 \mathrm{mg}$ pyridoxine hydrochloride; $0.2 \mathrm{mg}$ vitamin $\mathrm{B}_{12}$; $0.1 \mathrm{mg}$ biotin; $50 \mathrm{mg}$ niacin; $12 \mathrm{mg} \mathrm{D}$ - calcium pantothenate; $2 \mathrm{mg}$ folic acid; 80 mg Mn; 60 mg Fe; 8 mg Cu; 1 mg I; 0.3 mg Co; 1 mg Mo.
}

The gait-scoring test followed the 3-point scoring system developed by Webster et al. (2008) and Kestin et al. (1992). To conduct the test, two birds were randomly selected from each replicate group, and allowed to walk freely on the floor. The birds were then scored by visual observation against a number of criteria. On day 35, two birds per replicate were selected randomly, weighed and killed in a similar way to obtain the right tibia bone samples for measurements of bone strength and mineral concentration, meat yield 
and carcass fat content. Right tibia bones, collected on day 35, were boiled for 10 minutes in deionized water to remove all the soft tissue and defatted. Length and head width were measured using digital callipers (Mitutoyo, Japan) and the weight was recorded. The bones were then placed horizontally between brackets set $10 \mathrm{~mm}$ apart and the breaking strength was measured by positioning a $10 \mathrm{~mm}$ diameter compression rod against the bones and applying pressure (Lloyd, Hampshire, UK). After that, the bones were ashed at $550{ }^{\circ} \mathrm{C}$ for $4 \mathrm{~h}$ to measure the total ash content. The ash was further analysed using inductively coupled plasmaatomic emission spectrometry (ICP-AES) to determine the concentrations of calcium, phosphorus, magnesium, manganese, iron, copper and zinc.

Table 2 Composition of finisher diets

\begin{tabular}{|c|c|c|c|c|}
\hline & \multicolumn{4}{|c|}{ Experimental treatments $^{1}$} \\
\hline & SBM & CAN & SBF & CMF \\
\hline \multicolumn{5}{|l|}{ Ingredient composition (g/kg) } \\
\hline Maize & 412.7 & 393.4 & 430.0 & 413.0 \\
\hline Wheat & 200.0 & 200.0 & 210.0 & 230.0 \\
\hline Vegetable oil & 0.0 & 21.2 & 0.0 & 0.0 \\
\hline Soybean meal & 225.0 & 81.0 & 143.7 & 70.0 \\
\hline Canola meal & 75.0 & 243.0 & 71.8 & 140.0 \\
\hline Fish meal & 00.0 & 00.0 & 71.8 & 70.0 \\
\hline Limestone & 35.2 & 22.0 & 24.5 & 23.6 \\
\hline Dicalcium phosphate & 34.5 & 21.1 & 30.4 & 35.75 \\
\hline DL-Methionine & 1.4 & 1.5 & 1.7 & 1.6 \\
\hline L-Lysine & 2.0 & 2.6 & 1.8 & 1.8 \\
\hline Sodium chloride & 5.0 & 5.0 & 5.0 & 5.0 \\
\hline Vit.-min. premix ${ }^{2}$ & 2.5 & 2.5 & 2.5 & 2.5 \\
\hline Choline chloride & 0.6 & 0.6 & 0.6 & 0.6 \\
\hline Avizyme 1502 & 0.5 & 0.3 & 0.3 & 0.3 \\
\hline Phyzyme XP & 0.1 & 0.3 & 0.3 & 0.3 \\
\hline Zinc bacitracin & 0.5 & 0.5 & 0.5 & 0.5 \\
\hline Marker $\left(\mathrm{TiO}_{2}\right)$ & 5.0 & 5.0 & 5.0 & 5.0 \\
\hline \multicolumn{5}{|l|}{ Nutrient composition (g/kg) } \\
\hline $\mathrm{ME}(\mathrm{MJ} / \mathrm{kg})$ & 12.4 & 12.4 & 12.4 & 12.4 \\
\hline Crude protein & 191.5 & 191.4 & 191.5 & 191.1 \\
\hline Crude fibre & 28.0 & 36.5 & 28.0 & 33.0 \\
\hline Ether extract & 24.0 & 27.6 & 26.11 & 27.6 \\
\hline Calcium & 14.8 & 14.2 & 14.6 & 14.7 \\
\hline Available P & 5.6 & 5.6 & 5.7 & 5.6 \\
\hline Sodium & 2.3 & 2.4 & 2.7 & 2.7 \\
\hline Chloride & 3.3 & 3.3 & 3.7 & 3.7 \\
\hline Lysine & 12.3 & 12.0 & 12.4 & 12.4 \\
\hline Methionine+cysteine & 8.2 & 8.1 & 8.2 & 8.2 \\
\hline Threonine & 7.7 & 7.6 & 7.9 & 7.6 \\
\hline Arginine & 13.1 & 12.0 & 13.0 & 12.0 \\
\hline
\end{tabular}


Gross energy content of diets and ileal digesta were determined using an IKA bomb calorimeter (IKAWERKE, C7000, Staufen, Germany). The nitrogen content of digesta and diets was determined according to the Dumas combustion technique as described by Sweeney (1989), using a LECO FP-2000 automatic nitrogen analyser (LECO Corp., St. Joseph, MI, USA). Bone mineral was measured as per the method described by Anderson \& Henderson (1986). Copper, Fe, Mn, Zn, Ca, P and Mg were measured at $327 \mathrm{~nm}$, $238 \mathrm{~nm}, 257 \mathrm{~nm}, 213 \mathrm{~nm}, 616 \mathrm{~nm}, 231 \mathrm{~nm}$, and $279 \mathrm{~nm}$ wavelength, respectively. The $\mathrm{TiO}_{2}$ concentration of the digesta and diet samples was measured as per the method of Short et al. (1996). Aliquots of the solutions were obtained and, along with a similarly prepared standard solution, were analysed using a Hitachi150-20 UV spectrophotometer (Hitachi Science System Ltd., Ibaraki, Japan), measuring the absorbance at $410 \mathrm{~nm}$. Diets and ileal digesta were analysed for protein and gross energy as described above, and starch was determined with a Megazyme assay kit (Megazyme International Ireland, Bray Business Park, Bray, Ireland) as described by McCleary et al. (1994). The digestibility coefficient of nutrients was calculated according to the following equation:

Digestibility coefficient $=1-\left[\right.$ \{digesta nutrient $(\mathrm{g} / \mathrm{kg} \mathrm{DM}) /$ digesta $\left.\mathrm{TiO}_{2}(\mathrm{~g} / \mathrm{kg} \mathrm{DM})\right\} /$ diet nutrient $(\mathrm{g} / \mathrm{kg}$ $\mathrm{DM}) /$ diet $\mathrm{TiO}_{2}$ (g/kg DM)]

Excreta moisture content was determined according to the method described by the AOAC (2002). The $\mathrm{pH}$ of excreta samples was measured using a pH meter (Model LS, Sargent-Welch Co., Springfield, NJ). Excreta ammonia was measured as described in the Sigma-Aldrich ammonia assay kit (Catalogue Number AA0100), (Sigma-Aldrich, St. Louis, MO). The experimental protocol was approved by the Animal Ethics Committee of the University of New England, Australia (approval number AEC10/076). Statistical analyses were performed using Minitab software (Minitab version 15, 2000). The data were analysed using a one-way ANOVA with diet as factor. The significance of differences between means was determined by Fisher's least significant difference at $P \leq 0.05$.

\section{Results}

Results shown in Table 3 indicate that, during the period of days $1-21$, birds on the SBF diet consumed more $(P<0.001)$ feed $(1344 \mathrm{~g} / \mathrm{b})$ than birds fed the VP diets. Over the 1 - 35 day period, the CAN group consumed the most feed (3879 $\mathrm{g} / \mathrm{b}$ ) while the SBM group ate the least (3678 g/b). Feed intake was similar between the groups during the first week. Live weight gain was significantly greater for the birds fed the two AP diets (SBF; CMF) than the VP (CAN; SBM) diet groups during days 1 - $7(P<0.001)$, days 1 $21(P<0.001)$, and for the overall period $(P<0.05)$. Feed conversion ratio to 35 days was superior on the CMF diet while the birds on the CAN diet had the poorest conversion. Birds in the CMF diet group had similar FCR values to birds on SBF diet over 35 days, and this differed significantly $(P<0.05)$ from those on

Table 3 Growth responses of broiler chickens fed on different diets from hatch to 35 days

\begin{tabular}{|c|c|c|c|c|c|c|}
\hline & \multirow{2}{*}{ Days } & \multicolumn{4}{|c|}{ Experimental treatments $^{1}$} & \multirow{2}{*}{ Pooled SEM } \\
\hline & & SBM & CAN & SBF & CMF & \\
\hline \multirow[t]{3}{*}{ Feed intake (g/b) } & $1-7$ & 135.4 & 136.8 & 149.4 & 145.1 & 2.07 \\
\hline & $1-21$ & $1154.7^{\mathrm{c}}$ & $1252.7^{\mathrm{b}}$ & $1344.2^{\mathrm{a}}$ & $1290.4^{\mathrm{ab}}$ & $13.36^{* * *}$ \\
\hline & $1-35$ & 3677.7 & 3879.4 & 3856.6 & 3840.6 & 48.86 \\
\hline \multirow[t]{3}{*}{ Live weight gain(g/b) } & $1-7$ & $113.1^{\mathrm{b}}$ & $104.0^{\mathrm{b}}$ & $132.9^{\mathrm{a}}$ & $123.0^{\mathrm{a}}$ & $2.03^{* * *}$ \\
\hline & $1-21$ & $762.9^{b}$ & $784.0^{\mathrm{b}}$ & $900.6^{\mathrm{a}}$ & $909.6^{\mathrm{a}}$ & $12.28 * * *$ \\
\hline & $1-35$ & $2037.4^{\mathrm{b}}$ & $2110.5^{\mathrm{b}}$ & $2219.1^{\mathrm{a}}$ & $2228.3^{\mathrm{a}}$ & $24.56^{*}$ \\
\hline \multirow[t]{3}{*}{ Feed conversion ratio } & $1-7$ & $1.20^{\mathrm{b}}$ & $1.31^{\mathrm{a}}$ & $1.12^{\mathrm{c}}$ & $1.18^{\mathrm{bc}}$ & $0.017^{*}$ \\
\hline & $1-21$ & $1.51^{\mathrm{b}}$ & $1.59^{\mathrm{a}}$ & $1.50^{\mathrm{b}}$ & $1.42^{\mathrm{c}}$ & $0.020^{*}$ \\
\hline & $1-35$ & $1.80^{\mathrm{a}}$ & $1.84^{\mathrm{a}}$ & $1.73^{\mathrm{b}}$ & $1.72^{\mathrm{b}}$ & $0.017^{*}$ \\
\hline
\end{tabular}

${ }^{1}$ Experimental treatments as described in Table 1.

a, b, c Means within a row with different superscripts are significantly different at $* P<0.05$ and $* * * P<0.001$;

SEM: standard error of means. 
Table 4 Moisture, $\mathrm{pH}$ and ammonia concentration of excreta material of broilers

\begin{tabular}{lrrrrl}
\hline & \multicolumn{4}{c}{ Experimental treatments $^{1}$} & \multirow{2}{*}{ Pooled SEM } \\
\cline { 2 - 5 } & SBM & CAN & SBF & CMF & \\
\hline Moisture (\%) & $77.6^{\mathrm{a}}$ & $78.3^{\mathrm{a}}$ & $72.5^{\mathrm{b}}$ & $73.0^{\mathrm{b}}$ & \multirow{2}{*}{$0.64^{*}$} \\
$\mathrm{pH}$ & 7.4 & 7.4 & 7.2 & 7.3 & 0.07 \\
Ammonia (mg/L) & 10.0 & 10.1 & 9.3 & 9.4 & 0.98 \\
\hline
\end{tabular}

\footnotetext{
${ }^{1}$ Experimental treatments as described in Table 1.

Data represent mean values of eight replicate groups consisting of eight broiler chickens per replicate at 14 days of age.

${ }^{\mathrm{a}, \mathrm{b}}$ Means within a row with different superscripts differ significantly at $* P<0.05$.
}

the VP diets. The FCRs on the SBM, CAN, SBF and CMF diets were 1.80, 1.84, 1.73 and 1.72, respectively to 35 days. Mortality over the experimental period was similar, with no significant $(P=0.16)$ differences between treatments. The mortality rate to 21 days was nil in the CAN diet group, $6.2 \%$ in the SBM, and $4.6 \%$ in the SBF and CMF groups. Over the 35 days, mortality was $10.9 \%, 6.2 \%, 10.9 \%$ and $12.5 \%$ in the SBM, SBF, CAN and CMF groups, respectively, but not affected significantly $(P>0.05)$.

Higher $(P<0.05)$ moisture levels $(78.3$ and 77.6$)$ were found in the excreta of the VP diet groups (CAN and SBM, respectively) than of the AP diet groups (Table 4). Although the excreta $\mathrm{pH}$ values and the concentration of ammonia in the broilers fed the VP diets were higher than those of birds the AP diets, these differences were not significant $(P>0.05)$. Table 5 shows that protein digestibility was higher $(P<0.05)$ on the AP diets than on the VP diets. Gross energy and starch digestibility were not significantly $(P>0.05)$ affected by dietary treatment.

Table 5 Ileal digestibility of gross energy, protein and starch by chicks on different diets

\begin{tabular}{llllll}
\hline & \multicolumn{4}{c}{ Experimental treatments } & \multirow{2}{*}{ Pooled SEM } \\
\cline { 2 - 5 } & SBM & CAN & SBF & CMF & \\
\hline Gross energy & 0.77 & 0.77 & 0.78 & 0.77 & 0.058 \\
Protein & $0.77^{\mathrm{b}}$ & $0.76^{\mathrm{b}}$ & $0.81^{\mathrm{a}}$ & $0.80^{\mathrm{a}}$ & $0.007^{*}$ \\
Starch & 0.97 & 0.97 & 0.97 & 0.96 & 0.003 \\
& & & & & \\
\hline
\end{tabular}

\footnotetext{
${ }^{1}$ Experimental treatments as described in Table 1.

Data represent mean values of eight replicate groups consisting of four broiler chickens per replicate during the first 21 days.

${ }^{\text {a, }}$ Means within a row with different superscripts are significantly different at ${ }^{*} P<0.05$.
}

The results of the latency-to-sit and gait-scoring tests are presented in Table 6. Birds fed the SBF and CMF diets spent the longest $(P<0.05)$ time $(14.6$ and $13.3 \mathrm{~min})$ standing in the water, while birds on the SBM diet spent the shortest time (8.84 minutes). Statistically similar times (14.6 and $13.3 \mathrm{~min}$ ) were spent by the birds of CMF and SBF diet groups, respectively. There were no significant $(P>0.05)$ differences in the gait scores of the different dietary groups. However, comparatively higher scores were recorded on the SBM and CAN diets compared to the values recorded for both SBF and CMF.

The highest $(P<0.05)$ abdominal fat content $(24.9 \mathrm{~g})$ was found in the CMF diet and the lowest $(14.7$ g) was on the SBM diet (Table 7). The abdominal fat contents of broiler chickens fed animal protein diets were similar between treatments. Other characteristics such as dressing percentage, breast, drumstick, thigh, neck, giblet, shank and feather were not significantly different between dietary treatments. 
Table 6 Leg bone abnormalities measurement (latency-to-sit and gait-scoring tests)

\begin{tabular}{lcrrrl}
\hline & \multicolumn{4}{c}{ Experimental treatments $^{1}$} & \multirow{2}{*}{ Pooled SEM } \\
\cline { 2 - 5 } & SBM & CAN & SBF & CMF & \\
\hline Time spent (minutes) & $8.84^{\mathrm{c}}$ & $11.28^{\mathrm{b}}$ & $14.58^{\mathrm{a}}$ & $13.26^{\mathrm{a}}$ & $0.504^{*}$ \\
Gait score & 1.56 & 1.56 & 1.31 & 1.31 & 0.080 \\
& & & & & \\
\end{tabular}

\footnotetext{
${ }^{1}$ Experimental treatments as described in Table 1.

Data represent mean values of eight replicate groups of four chickens taken at 28 days of age.

${ }_{\text {a, b, c }}$ Means within a row with different superscripts differ significantly at $* P<0.05$.
}

Table 7 Carcass characteristics and meat yield (g/b) of chickens

\begin{tabular}{lrrrrr}
\hline & \multicolumn{4}{c}{ Experimental treatments $^{1}$} & \multirow{2}{*}{ Pooled SEM } \\
\cline { 2 - 5 } & SBM & CAN & SBF & CMF & \\
\hline Feather & 92.8 & 88.4 & 117.8 & 115.4 & 6.04 \\
Carcass weight & 1558.0 & 1644.0 & 1640.0 & 1667.0 & 27.05 \\
Dressing percentage & 74.6 & 74.5 & 74.0 & 73.9 & 0.38 \\
Breast & 519.0 & 496.7 & 519.4 & 519.0 & 9.26 \\
Drumstick & 186.0 & 190.5 & 191.3 & 197.2 & 2.89 \\
Thigh & 218.8 & 224.4 & 218.5 & 229.6 & 4.32 \\
Abdominal fat & $14.7^{\mathrm{c}}$ & $18.2^{\mathrm{b}}$ & $20.2^{\mathrm{a}}$ & $24.9^{\mathrm{a}}$ & $0.87^{*}$ \\
Giblet & 117.3 & 114.4 & 119.2 & 118.4 & 2.46 \\
Shank & 52.7 & 51.6 & 53.6 & 56.3 & 0.99 \\
Neck & 58.7 & 59.6 & 61.3 & 62.5 & 0.99 \\
\hline
\end{tabular}

1 Experimental treatments as described in Table 1.

Data represent mean values of two chickens of eight replicate groups taken at the end of 35 day trial period;

${ }^{a, b}, \mathrm{c}$ Means within a row with different superscripts are significantly different at $* P<0.05$.

The results of bone characteristics (length, weight, width, breaking strength), and total bone ash and bone mineral concentrations are presented in Tables 8 and 9, respectively. Birds on the CMF diet had the longest $(P<0.05)$ tibia bone $(67.1 \mathrm{~mm})$, while those on SBM had the shortest $(62.9 \mathrm{~mm})$. Bone length for the other dietary groups was 65.7 and $64.7 \mathrm{~mm}$, respectively, in the SBF and CAN groups. Similarly, birds on SBF had the highest $(P<0.05)$ bone breaking strength $(31.3 \mathrm{~kg})$. The lowest bone strength $(21.5 \mathrm{~kg})$ was recorded in birds fed the SBM diet (Table 8). Statistically similar bone strength of $31.3 \mathrm{~kg}, 30.0 \mathrm{~kg}$ and 28.2 $\mathrm{kg}$ were found in birds fed the SBF, CMF and CAN diets, respectively.

Bone ash content of birds on the CMF diet was the highest $(1.70 \mathrm{mg} / \mathrm{g})$, while the birds on SBM diet had the lowest $(1.51 \mathrm{mg} / \mathrm{g})$ bone ash content. Diets SBF and CMF produced a similar bone ash content, but differed significantly $(P<0.001)$ from other diet groups. Macro-mineral concentrations ( $\mathrm{Ca}, \mathrm{P}$ and $\mathrm{Mg}$ ) on various treatments were identical. Of the micro-mineral concentrations, only $\mathrm{Fe}$ and $\mathrm{Cu}$ differed $(P<0.05)$ between diet groups, with the highest concentrations ( $\mu \mathrm{g} / \mathrm{g}$ bone ash) of $\mathrm{Fe}(2.86)$ and $\mathrm{Cu}(0.048)$ in the CMF diet group, while the CAN and SBM diet groups contained the lowest concentrations of 2.29 and 0.030 , respectively. Statistically similar Cu concentrations of $0.03 \mu \mathrm{g} / \mathrm{g}, 0.032 \mu \mathrm{g} / \mathrm{g}$ and $0.033 \mu \mathrm{g} / \mathrm{g}$ bone ash were found in the bones of birds fed SBM, CAN and SBF diets, respectively. The Fe concentration of CAN diet group of birds was also similar to that of the SBF diet group. 
Table 8 Bone (right tibia) characteristics and quality of broiler chickens

\begin{tabular}{lccccc}
\hline & \multicolumn{4}{c}{ Experimental treatments ${ }^{1}$} & \multirow{2}{*}{ Pooled SEM } \\
\cline { 2 - 5 } & SBM & CAN & SBF & CMF & \\
\hline Length of bone (mm) & $62.9^{\mathrm{c}}$ & $64.7^{\mathrm{b}}$ & $65.7^{\mathrm{b}}$ & $67.1^{\mathrm{a}}$ & $0.37^{*}$ \\
Weight of bone (g/kg body & 3.5 & 3.4 & 3.6 & 3.7 & 0.07 \\
weight of bird) & 11.5 & 11.3 & 11.9 & 11.6 & 0.12 \\
Width of bone (mm) & $21.5^{\mathrm{c}}$ & $28.2^{\mathrm{ab}}$ & $31.3^{\mathrm{a}}$ & $30.0^{\mathrm{a}}$ & $1.05^{*}$ \\
Breaking strength (kg ) & & & & &
\end{tabular}

${ }^{1}$ Experimental treatments as described in Table 1.

Length and width of bone are measured in millimetres per bone per bird; breaking strength is expressed in $\mathrm{kg}$ force required to break each bone per bird.

${ }_{\text {a, b, c }}$ Means within a row bearing uncommon superscripts in a row are significantly different at $* P<0.05$.

Table 9 Mineral concentrations in tibia bone

\begin{tabular}{|c|c|c|c|c|c|}
\hline & \multicolumn{4}{|c|}{ Experimental treatments $^{1}$} & \multirow{2}{*}{ Pooled SEM } \\
\hline & SBM & CAN & SBF & CMF & \\
\hline $\begin{array}{l}\text { Tibia bone ash (mg/g } \\
\text { bone weight) }\end{array}$ & $1.51^{\mathrm{c}}$ & $1.57^{\mathrm{b}}$ & $1.64^{\mathrm{a}}$ & $1.70^{\mathrm{a}}$ & $0.009 * * *$ \\
\hline \multicolumn{6}{|c|}{ Macro minerals (g/kg bone ash) } \\
\hline Calcium & 236.30 & 243.60 & 246.60 & 246.50 & 3.500 \\
\hline Phosphorus & 111.00 & 112.30 & 113.20 & 114.30 & 1.520 \\
\hline $\begin{array}{l}\text { Magnesium ( } \mu \mathrm{g} / \mathrm{g} \\
\text { bone ash) }\end{array}$ & 47.62 & 46.77 & 45.88 & 46.98 & 0.618 \\
\hline \multicolumn{6}{|c|}{ Trace minerals ( $\mu \mathrm{g} / \mathrm{g}$ bone ash) } \\
\hline Magnesium & 47.62 & 46.77 & 45.88 & 46.98 & 0.618 \\
\hline Manganese & 0.063 & 0.057 & 0.058 & 0.048 & 0.0024 \\
\hline Zinc & 3.36 & 2.66 & 2.77 & 2.81 & 0.132 \\
\hline Iron & $2.78^{\mathrm{b}}$ & $2.29^{c}$ & $2.43^{c}$ & $2.86^{\mathrm{a}}$ & $0.074^{*}$ \\
\hline Copper & $0.03^{\mathrm{b}}$ & $0.032^{\mathrm{b}}$ & $0.033^{b}$ & $0.048^{\mathrm{a}}$ & $0.0019 *$ \\
\hline
\end{tabular}

${ }^{1}$ Experimental treatments as described in Table 1.

Data represent means of eight replicates of 2 chicken right tibia bones at age of 35 days.

a, b, c Means within a row with different superscripts differ significantly at $* P<0.05$; *** $P<0.001$.

\section{Discussion}

From the current study it is clear that the gross response of broiler chickens fed AP diets was better than that of birds receiving the VP diets. Birds fed AP diets attained significantly higher body weight gain and better feed efficiency over the entire trial period. The results suggest that the positive response to AP diets was mainly because of the increase in feed intake. A similar increase in feed intake by broilers fed AP diets was reported by Bhuiyan et al. (2012a; b) without any improvement in growth. The difference in growth response between the studies might be owing to variation in feed composition and formulation. The diets used in the current study were formulated on the basis of total amino acids, unlike those in the study by Bhuiyan et al. (2012a; b), who formulated on the basis of digestible amino acids. The latter would generally yield diets that are more balanced in amino acids, regardless of the source of protein.

The FCR was improved on the AP diets compared with the VP diet groups. This difference may be because of better protein digestibility of the AP diets as well as increased efficiency in utilization of energy, 
as recently reported by Hossain et al. (2012a; b) in a trial on similar diets. Our findings are in agreement with Solangi et al. (2002) and Alali et al. (2011), who reported that fish meal and other animal protein meals increase feed intake and enhance the feed efficiency of broiler chickens. However, these responses may not always be statistically significant with all animal products or feed formulations, as observed by Bhuiyan et al. (2012a) in studies on high-quality meat meal.

The birds on the VP diets voided excreta with a significantly higher moisture content than those on the AP diets. The moisture content of the excreta of broilers in the VP groups was about $5 \%$ higher than levels in the AP diet groups. Many dietary factors, including protein level, electrolytic balance, ionophores, cereal/fibre/legume contents and non-starch polysaccharides (NSPs) are known to affect excreta/litter moisture and quality (Smith et al., 2000; Murakami et al., 2001). Our findings support the results of Vieira \& Lima (2005) and Eichner et al. (2007), who reported that broilers fed diets formulated solely with vegetable ingredients produce a higher amount of moisture and ammonia in their excreta. This excess moisture affects the litter quality adversely and leads to an increased risk of footpad dermatitis and other diseases.

Ileal protein digestibility in the VP diets was lower than in the AP diets. This finding supports the report of Vieira \& Lima (2005). This may partly be responsible for the better growth of broiler chickens on the AP diets observed in this study. The poor protein digestibility of VP diets may be owing to various factors, including the presence of ANF, the nature of the protein and amino acid balance, as well as a higher proportion of crude fibre of vegetable feeds (Hossain et al., 2011b). No two protein sources are similar in properties such as mode of digestibility, biological value, protein quality, and physical and chemical properties (Sing \& Panda, 1992). These characteristics of individual protein sources may affect the protein digestibility and performance of birds when used in feed formulation. However, several researchers (Gatel, 1994; Smits \& Annison, 1996) reported that the major factor limiting the use of vegetable proteins in practical diets is the existence of naturally occurring deleterious factors, including NSP, tannins and trypsin inhibitors, which have adverse effects on nutrient digestibility and absorption. Although properly processed oilseed meals may have little or no residual ANF, the complex structure, physical and chemical properties of all-vegetable diets might prevent the birds from obtaining full nutritional benefits by suppressing their nutrient digestibility and energy utilization. In this study, the ileal energy digestibility of broilers of all dietary groups was similar, which would be because similar cereals (maize and wheat) constituted the major proportion of the basal diets.

The results of the LTS test show better leg bone development in birds on the AP diets than was observed with the gait scores. Berg \& Sanotra (2003) found dissimilar results between the LTS and gaitscoring data, the latter being more subjective than the former. The poor leg health of broilers on the VP diets (SBM; CAN) may have resulted from the phytate content of the plant feeds, although these diets were supplemented with microbial enzymes. The anti-nutritive properties of phytate may not have been completely eliminated by phytase supplementation (Selle \& Ravindran, 2007).

Most of the meat yield traits were similar, and the differences between treatment groups were nonsignificant. These findings support the report of Al-Masri (2003), who observed no significant differences in the various carcass traits of broiler chickens fed VP diets and those fed AP diets, with meat-bone meal or fish meal as animal protein. The difference in the abdominal fat content observed in this study was similar to the findings of previous researchers who evaluated diets containing animal proteins (Janocha \& Milczarek, 2006). The probable reason for the increase in abdominal fat on AP diets may be more rapid growth, leading to earlier transition from muscle to fat deposition.

Although there were no significant differences in the macro-mineral concentration from different diet groups, total bone ash contents of the birds on AP diets were significantly higher than those of birds on VP diets in this study. The increased length, width and weight of bones of the birds on the AP diets may contribute to higher bone ash content in birds fed on these diets. Apart from this, despite the lack of major differences in bone macro-mineral concentrations between treatments, the major mineral elements, $\mathrm{Ca}$ and $\mathrm{P}$, which are closely related to bone development, were found in comparatively higher concentrations in the bones of broilers fed the AP diets than those fed the VP diets. Conversely, the concentrations of Mg and Mn were found to be slightly higher in birds on the VP diets than those on the AP diets. However, these two minerals are only required in trace amounts and may contribute less to bone development than $\mathrm{Ca}$ and $\mathrm{P}$. The higher concentrations of $\mathrm{Cu}$ and Fe in bone ash in birds on the CMF diet may stimulate bone growth and increase bone strength, as these trace minerals are linked to use of the main minerals, Ca and $\mathrm{P}$, in bone development (Medeiros et al., 1997). 


\section{Conclusion}

The present study shows that broiler chickens fed on AP diets had comparatively better performance, in terms of feed intake, live weight gain and FCR than those fed VP diets. This may be owing to higher ileal digestibility of protein and better bone development on the former diets than on the latter. However, chicks on AP diets were fatter than those on VP diets. It is not known whether and how these results will be sustained if diets were formulated based on digestible rather than total amino acids. A recommendation of either set of diets would also depend on a full economic analysis of the costs associated with their feeding.

\section{Acknowledgement}

The project was funded by the UNE, Australia, and Danisco Animal Nutrition, UK, supplied the enzyme.

\section{References}

Alali, W.Q., Hofacre, C.L., Mathis, G.F. \& Batal, A.B., 2011. Effect of plant-based protein meal use in poultry feed on colonization and shedding of Salmonella Heidlberg in broiler birds. Agric. Food. Anal. Bacteriol. J. 1, 45-53.

Al-Masri, M.R., 2003. Effect of feeding broiler chicks a completely vegetable finishing ration on the apparent metabolizable energy, total protein efficiency and carcass marketing properties. Report on Scientific Laboratory Study, no. 496/RSS. Atomic Energy Commission, Damascus, Syria. pp. 1-50.

Anderson, D.L. \& Henderson, L.J., 1986. Sealed chamber digestion for plant nutrient analysis. Agron. J. 78, 937-938.

AOAC, 2002. Official Methods of Analysis (17th ed.). Association of Official Analytical Chemists, Inc., Maryland, USA.

Berg, C. \& Sanotra, G.S., 2003. Can a modified latency to lie test be used to validate gait-scoring result in commercial broiler flocks? Anim. Welf. 12, 655-659.

Bhuiyan, M.M., Clatworthy, G. \& Iji, P.A., 2012a. Vegetable protein diets are adequate but broiler chickens prefer animal protein diets. Wrld's Poult. Sci. J. 68 (Suppl. 1), CD-ROM.

Bhuiyan, M.M., Hossain, M.A. \& Iji, P.A., 2012b. Preference of broiler chickens for animal and vegetable protein diets. Australas. Med. J. 5, 657.

Eichner, G, Vieira, S.L., Torres, C.A., Coneglian, J.L.B., Freitas, D.M. \& Oyarzabal, O.A., 2007. Litter moisture and footpad dermatitis as affected by diets formulated on an all-vegetable basis or having the inclusion of poultry by-product. J. Appl. Poult. Res.16, 344-350.

Gatel, F., 1994. Protein quality of legume seeds for non ruminant animals: A literature review. Anim. Feed Sci. Technol. 45, 317-348.

Giang, V.D., Chinh, B.V., Huyen, D.V. \& Ha, N.N., 2001. Potential and characteristics of animal feeds in Vietnam. Composition and Nutritive Values of Animal Feeds in Vietnam. Agricultural Publishing House, Hanoi, Vietnam. pp. 22-36.

Hossain, M.A., Islam, A.F. \& Iji, P.A., 2011a. Performance of broiler chickens fed diets based on allvegetable ingredients. Rec. Adv. Anim. Nutr. Aust. 18, 99-100.

Hossain, M.A., Islam, M.M, Islam, A.F. \& Iji, P.A., 2011b. Constraints to use of all-vegetable feed ingredients and strategies to improve such diets for poultry birds: A Review. Bangladesh Res. Pub. J. 6, 120-135.

Hossain, M.A., Islam, A.F. \& Iji, P.A., 2012a. Energy utilization and growth responses of broiler chickens on vegetable protein diets. Proc. Aust. Poult. Sci. Symp., Syd, Aust. 23, 276-279.

Hossain, M.A., Islam, A.F. \& Iji, P.A., 2012b. Energy utilization and performance of broiler chickens raised on diets with vegetable proteins or conventional feeds. Asian J. Poult. Sci. 6, 117-128.

Janocha, A. \& Milczarek, A., 2006. The effects of vegetable diets in slaughter yield and fatty acid profile of meat in broiler chickens. Roczniki Instytutu Przemysu Miesnego I Tuszczowego 44, 71-79.

Kestin, S.C., Knowles, T.G., Tinch, A.E. \& Gregory, N.G., 1992. Prevalence of leg weakness in broiler chickens and its relationship with genotype. Vet. Rec. 131, 190-194.

Liener, I.E., 1980. Toxic constituents of plant foodstuffs. Second edition, New York and London, Academic Press. 502 p. 
McCleary, B.V., Solah, V. \& Gibson, T.S., 1994. Quantitative measurement of total starch in cereal flours and products. J. Cereal Sci. 20, 51-58.

Medeiros, D.M., Ilich, J., Ireton, J., Matkovic, V., Shiry, L. \& Wildman, R., 1997. Femurs from rats fed Diets deficient in copper or iron have decreased mechanical strength and altered mineral composition. J. Trace Elem. Exp. Med.10, 197-203.

Mendes, A.A., 2003. Rastreabilidade official avícola em discussão [citado em 2005 jan]. Disponível em: http://www.dipemar.com.br/carne/315/materia_especial_carne.htm. (in: Portuguese)

Minitab, 2000. Minitab Statistical Software User's Guide 2: Data Analysis and Quality Tools. Minitab Inc., State College, P.A., USA.

Murakami, A.E., Oviedo-Rondon, E.O., Martins, E.N., Pereira, M.S. \& Scapinello, C., 2001. Sodium and chloride requirements of growing broiler chickens (21 to 42 days of age) fed corn-soybean diets. Poult. Sci. 80, 289-294.

NRC, 1994. Nutrient Requirement of Poultry, $9^{\text {th }}$ Revised Edition, National Research Council. National Academy Press, Washington, D.C., USA.

Oluyemi, J.A. \& Roberts, F.A., 2000. Poultry Production in warm wet climates. Macmillan Press Ltd. $2^{\text {nd }}$ Ed. Spectrum Books Ltd. Ibadan, Nigeria.

Parsons, C.M., Castanon, F. \& Han., Y., 1997. Protein and amino acid quality of meat and bone meal. Poult. Sci. 76, 361-368.

Selle, P.H. \& Ravindran, V., 2007. Microbial phytase in poultry nutrition. Anim. Feed Sci. Technol. 135, $1-41$.

Short, F.J., Gorton, P., Wiseman, J. \& Boorman, K.N., 1996. Determination of titanium dioxide added as an inert marker in chicken digestibility studies. Anim. Feed Sci. Technol. 59, 215-221.

Sing, K.S. \& Panda, B., 1992. Poultry Nutrition. Kalyani Publishers, New Delhi, India. pp. 57-61.

Smith, A., Rose, S.P., Well, R.G. \& Pirgozliev, V., 2000. Effect of excess dietary sodium, potassium, calcium, and phosphorus on excreta moisture of laying hens. Br. Poult. Sci. 41, 598-607.

Smits, C.H.M. \& Annison, G., 1996. Non-starch polysaccharides in broiler nutrition towards a physiologically valid approach to their determination. Wrld's Poult. Sci. J. 52, 203-221.

Solangi, A.A., Memon, A., Qureshi, T.A., Leghari, H.H., Baloch, G.M. \& Wagan, M.P., 2002. Replacement of fishmeal by soybean meal in broiler ration. J. Anim. Vet. Adv. 1, 28-30.

Sweeney, R.A., 1989. Generic combustion method for determination of crude protein in feeds: Collaborative study. J. Assoc. Off. Anal. Chem. 72, 770-774.

Tacon, A.G.J., 1992. Nutritional fish pathology: morphological signs of nutrient deficiency and toxicity in farmed fish. FAO Fisheries Technical Paper No.330, FAO, Rome. 75 p.

Vieira, S.L. \& Lima, I.L., 2005. Live performance, water intake and excreta characteristics of broiler fed all vegetable diets based on corn and soybean meal. Int. J. Poult. Sci. 4, 365-368.

Webster, A.B., Fairchild, B.D., Cummings, T.S. \& Stayer, P.A., 2008. Validation of a three point gait scoring system for field assessment of walking ability of commercial broilers. J. Appl. Poult. Res. 17, 529-539. 